Laskowska, A. (2018). Stock market indices as a measurement tool for profitability of corporate social responsibility activities. Copernican Journal of Finance \& Accounting, 7(4), 71-86. http:// dx.doi.org/10.12775/CJFA.2018.021

\author{
ANNA LASKOWSKA* \\ Nicolaus Copernicus University in Toruń
}

\title{
STOCK MARKET INDICES \\ AS A MEASUREMENT TOOL FOR PROFITABILITY OF CORPORATE SOCIAL RESPONSIBILITY ACTIVITIES
}

Keywords: corporate social responsibility, socially responsible investing, socially responsible stock indices, sustainability stock market indices.

J E L Classification: G11, M14, 016.

Abstract: Corporate social responsibility is gaining more importance in the functioning of businesses, therefore, tools are being developed to assess these activities, such as socially responsible stock indices. The research objective of the article is to characterise global and Polish socially responsible indices, as well as to measure and evaluate their profitability compared to traditional stock indices. The research methods applied in the paper are: subject literature analysis, statistical data analysis, secondary research analysis and own research in the form of calculating return rates and Sharpe ratios for RESPECT Index and WIG. The outputs of the analyses of the effectiveness of Polish and global indices will be compared to research hypotheses relating to socially responsible portfolios. The outcome of the article is to specify the key conclusions in the field of corporate social responsibility investment efficiency and stock market indices as a tool of measuring these activities.

Date of submission: April 9, 2019; date of acceptance: May 2, 2019.

* Contact information: anna.las@doktorant.umk.pl, Nicolaus Copernicus University in Toruń, Gagarina 13a, 87-100 Toruń, Poland, phone: +48 5661146 34; ORCID ID: https://orcid.org/0000-0002-4103-4755. 


\section{INTRODUCTION}

Corporate social responsibility is gaining more importance in the functioning of businesses. In present times, the financial sector requires that its participants not only take actions to maximise the profit, but they also consider social, ethical, environmental and social responsibility issues - in short: social responsibility. Such measures adopted by market participants forced the creation of tools evaluating the actions with the stock market index as one of the instruments. It was designed to analyse the profitability of corporate social responsibility activities, thereby helping with making sustainable decisions.

The aim of the article is to characterise global and Polish socially responsible indices, as well as to measure and evaluate their profitability compared to traditional stock indices. The first part of the article contains a discussion over the concept of corporate social responsibility and the measurement of socially responsible strategies. The second part, except for the presentation of the functions of indices on the capital market, provides and overview of the origin and characteristics of socially responsible indices in Poland and in the world, as well as analyses their profitability.

\section{THE RESEARCH METHODOLOGY AND THE COURSE OF THE RESEARCH PROCESS}

The following research methods were applied when preparing the article: subject literature analysis, statistical data analysis, secondary analysis on the subject of selected researches relating to the profitability of global sustainability stock market indices and own research on the profitability of Polish stock market indices in the form of calculating return rates and Sharpe ratios for RESPECT Index and WIG. The return rates were calculated for the following periods: 1 month, 3 months, 6 months, 1 year 5 years and 10 years (from the first day of the RESPECT Index quotation). Sharpe ratio of RESPECT Index and WIG was calculated for the period 2017-2018. The outputs of the analyses of the effectiveness of Polish and global indices will be compared to research hypotheses relating to socially responsible portfolios, resulting in conclusions regarding the cost-efficiency of the CSR/SRI strategy. The profitability of socially responsible activities is also defined in the article by the expressions: effectiveness, viability. The content of the elaboration shows that the 'profitability', 'effectiveness' and 'viability' are treated in the paper as a measure of market profits earned on corporate social responsibility companies. 


\section{THE CONCEPT OF CORPORATE SOCIAL RESPONSIBILITY}

Corporate social responsibility (CSR), often referred to as corporate social enterprise, is a multidimensional and universal term and therefore it seems impossible to formulate its unequivocal, perfect and indisputable definition.

Corporate social responsibility has long been an essential element of economic policy of the European Community. In 2001 the European Commission issued Green Paper: Promoting a European Framework for Corporate Social Responsibility, the first EU document dedicated to the area of CSR. The Green Paper defines corporate social responsibility as voluntary incorporation of social and ecological issues into economic activity and stakeholder relations (Commission of the European Communities, 2001).

Exactly 10 years later the European Commission updated the notion of CSR, issuing the communication The European Commission's strategy on CSR 20112014: achievements, shortcomings and future challenges. The Commission formulates the idea of CSR as "responsibility of enterprises for their impacts on society". The renewed strategy expresses the European Community concern about the concept of CSR. The Commission also noted that issuing a new definition and Communication is related to the economic crisis how it affected the society, namely the loss of confidence in the business sector. By taking measures to promote CSR the Commission expects to shape responsible business attitudes and ensure economic growth in accordance with sustainable development principles (European Commission, 2011).

When defining corporate social responsibility, the subject literature is not homogenous either. Table 1 presents a review of how the meaning of CSR was changing in years 1963-2011.

Table 1. A review of selected definitions for corporate social responsibility

\begin{tabular}{|l|l|}
\hline \hline \multicolumn{1}{|c|}{ Author/Source } & \multicolumn{1}{c|}{ Definition } \\
\hline \hline McGuire, 1963 & $\begin{array}{l}\text { the concept assumes that a company not only has economic or legal obliga- } \\
\text { tions but also other responsibilities towards society }\end{array}$ \\
\hline Sethi, 1975 & $\begin{array}{l}\text { the obligation to introduce corporate behaviour, which befits existing so- } \\
\text { cial norms, values and environment expectations }\end{array}$ \\
\hline Jones, 1980 & $\begin{array}{l}\text { a company's voluntarily accepted obligation towards all its stakeholders } \\
\text { - shareholders as well as other groups connected with the activity of the } \\
\text { enterprise, namely clients, employees, suppliers and the entire local com- } \\
\text { munity }\end{array}$ \\
\hline
\end{tabular}


Table 1. A review of selected definitions...

\begin{tabular}{|c|c|}
\hline Author/Source & Definition \\
\hline Zbiegień-Maciąg, 1996 & $\begin{array}{l}\text { the enterprise morality and accountability before the law and society for } \\
\text { the actions taken, especially before owners, employees, clients, share- } \\
\text { holders, banks, creditors, suppliers, local authorities, state administration, } \\
\text { consumer or ecological movements }\end{array}$ \\
\hline Rok, 2001 & $\begin{array}{l}\text { the philosophy of managing a service and production activity, aimed at } \\
\text { building long-term and positive relations with all the parties involved }\end{array}$ \\
\hline Grzybowski, 2004 & $\begin{array}{l}\text { an element of a company's strategy (marketing management) fostering } \\
\text { the fulfilment of economic aims, consisting in developing positive relations } \\
\text { with groups which may affect the prosperity of the business }\end{array}$ \\
\hline Chandler and Werther, 2006 & $\begin{array}{l}\text { relations between corporations (or other large organizations) and the soci- } \\
\text { ety (namely all stakeholder groups who maintain their interest in the activ- } \\
\text { ity of an institution) they cooperate with }\end{array}$ \\
\hline Lawrence and Weber, 2008 & $\begin{array}{l}\text { the obligation to take responsibility for every action with has an impact } \\
\text { on the society (people or natural environment), which means confessing } \\
\text { to negative accidents caused by the company and correcting the results } \\
\text { of such actions }\end{array}$ \\
\hline Łudzińska, 2009 & $\begin{array}{l}\text { the duty of men in charge to make decisions and take up activities, which } \\
\text { contribute to concern for both vested interest (namely increasing the com- } \\
\text { pany's profit) as well as the securing and multiplying of the social welfare }\end{array}$ \\
\hline Bartkowiak, 2011 & $\begin{array}{l}\text { the influence of business decisions and all the company's interaction with } \\
\text { other market entities - inside and outside the organization }\end{array}$ \\
\hline
\end{tabular}

Source: elaborated by the author based on the literature of the subject listed above and (Łukasiewicz-Kamińska, 2011).

Understanding of the motivation for running a company has changed over the years. It can be spotted that the theory implying the maximising of a company's profit as the priority goal of its functioning is gradually being abandoned, in favour of corporate social responsibility strategies. For a long time the business communication with the environment has based on investor relations. They attached particular importance to current and potential investors of a company and the communication was financial and economic in nature (Dziawgo, 2011, pp. 23-24). Due to the capital involved, this group bears the highest risk and therefore they have the greatest information needs. Since the revolution in communication technology, globalisation and popularisation of social responsibility, such communication is perceived as insufficient and the satisfaction of investors, although still important, should not be the only goal of a company. The new need for the communication with environment to embrace a wider public resulted in the stakeholder theory, namely groups the company 
has impact on or towards which it has certain commitments affecting the business (Roszkowska, 2011, pp. 48-51).

The stakeholder theory introduces a wider perspective on the significance and role of a company in the environment. It also underlines the role and importance of other groups when the value of the company is being created. It is stakeholders whose expectations towards the company are much greater than just economic (table 2). They require that environmental, social and governance (ESG) factors are included in the management process (PaliwodaMatiolańska, 2009, pp. 74-75).

Table 2. Stakeholders' expectations

\begin{tabular}{|c|c|c|}
\hline \multicolumn{2}{|c|}{ Stakeholders } & \multirow{2}{*}{$\begin{array}{l}\text { Expectations } \\
\text { Growth of the company's value } \\
\text { Maximising the value of shares } \\
\text { Complete and reliable information } \\
\text { Competent authorities } \\
\text { Enhancing the company's image }\end{array}$} \\
\hline Substantial & Shareholders and owners & \\
\hline & Employees & $\begin{array}{l}\text { Satisfying salaries } \\
\text { Fulfilling the duties towards employees } \\
\text { Complete and reliable information } \\
\text { Job satisfaction, development opportunities }\end{array}$ \\
\hline \multirow[t]{4}{*}{ Contract } & Contractors and suppliers & $\begin{array}{l}\text { Financial credibility of the partner } \\
\text { Operational ethics } \\
\text { Culture and professionalism in actions } \\
\text { Cooperating } \\
\text { Quality of the communication process }\end{array}$ \\
\hline & Customers & $\begin{array}{l}\text { Quality of the product or service } \\
\text { Clear, transparent and accessible information } \\
\text { Building customer relationship } \\
\text { Company's image }\end{array}$ \\
\hline & Competition & $\begin{array}{l}\text { Fair competition } \\
\text { Culture in business activities }\end{array}$ \\
\hline & Financial institutions & $\begin{array}{l}\text { Credible financial results } \\
\text { Transparency, reliability and comprehensiveness of information } \\
\text { Competent authorities }\end{array}$ \\
\hline \multirow[t]{2}{*}{ Context } & $\begin{array}{l}\text { Government and social } \\
\text { institutions }\end{array}$ & $\begin{array}{l}\text { Compliance with legal norms of public-legal liabilities } \\
\text { Supporting charity institutions } \\
\text { Assisting the activities or political parties }\end{array}$ \\
\hline & Community & $\begin{array}{l}\text { Prosocial activities } \\
\text { Patronage over cultural, scientific and sports events } \\
\text { Environmental protection } \\
\text { Company's civil approach towards local environment }\end{array}$ \\
\hline
\end{tabular}

S o u r c e : the author's elaboration based on: (Wawrzyniak, 1999, p. 215; Paliwoda-Matiolańska, 2009, p. 61; Jamka, 2011, pp. 42-43). 
The table above presents the expectations a company willing to act in a socially responsible way should take into consideration in its current activities. Extending the interest to a wider public does not mean that the investors are being overlooked, as they are still one of the essential groups of stakeholders. The approach that companies applying the CSR strategy and communicating transparently are less risky and more attractive is gaining popularity. Considering ESG factors in the process of investment decisions is referred to as socially responsible investing (SRI). This investment strategy aims as both maximising the profit and achieving social good. The idea of SRI resulted in the emergence of socially responsible financial instruments (Boatright, 2010, pp. 397-400).

According to Czerwonka (2013, pp. 21-23), there are four basic criteria, both in the concept of CSR, as well as SRI: ecological, social, religion-related, sustainability. This is one of the main connecting elements of the notions. What should be noted, is that there is a close relation between CSR and SRI ideas. The major similarity of the two concepts results from the fact, that SRI is an investment counterpart of corporate social responsibility.

\section{MEASUREMENT OF CORPORATE SOCIAL RESPONSIBILITY STRATEGIES}

Taking up corporate social responsibility activities by a company resulted in the need to create appropriate measuring instruments. However, it is difficult to determine the direct impact of socially responsible activities on financial results. Although the costs related to the implementation of CSR strategies can be calculated accurately, the benefits are extended over time and difficult to quantify, due to the number of stakeholders. Lulewicz-Sas (2013, pp. 248-249) points out that when analysing the effect of corporate social responsibility on the company's value, one has to concentrate on the factors having positive indirect influence on the value, i.e. product quality, stakeholders relationship, the company's reputation and trust.

Despite numerous methods of CSR measurement, objective evaluation is impossible because of the lack of one specific tool that would allow to determine economic efficiency of sustainable activities (Czopik, 2017, p. 241). According to Wronka, seven categories of CSR measuring instruments can be itemised (2011, p. 261):

1) benchmarking of achievements and rating tools,

2) content analysis of corporate publications,

3) certification and accreditation, 
4) reporting guidelines,

5) networks based on voluntary participation,

6) evaluation scales

7) creating sub-indices under Balanced Scorecard.

The first instrument is utilized in this article: benchmarking of achievements and rating tools - stock market indices of socially responsible companies.

\section{SOCIALLY RESPONSIBLE STOCK INDICES}

Socially responsible stock market indices, also known as sustainability stock market indices, are extremely useful tools when making socially responsible investment decisions.

The stock market indices play an important function on financial market and they key role is to organise the capital market by identifying companies meeting the relevant CSR criteria and observing the efficiency of socially responsible investments. The fundamental objective of sustainability stock market indices is to guarantee financial advisors and investors a certain point of reference (benchmark) which allows to evaluate socially responsible portfolios. It may therefore be concluded that CSR indices serve the role of a compass for investors who want to allocate funds according to SRI principles. It should also be noted that certain indices list only some companies from the large group under analysis. As a result, companies included in CSR indices disseminate the information immediately. Therefore, sustainability stock market indices can be regarded as a promotion tool for the listed companies (Dziawgo, 2010, p. 54).

Another advantage of CSR indices is the development of capital market, as they form the basis for creating new instruments. For example, iShares MSCI KLD 400 Social ETF and FTSE4FOOD IBEX ETF were formed basing on ETF index funds (Wolska \& Czerwonka, 2013, p. 15).

There are also specialised CSR indices, concentrating on one SRI area only. In this respect, there is a large number of environmental stock indices on the capital market, such as Nasdaq Clean Edge Green Energy Index, Cleantech Index, Next-Generation Energy Index, FTSE Green Revenues Index and S\&P Global Water Index.

Just alike the idea of SRI, also sustainability stock indices are gaining popularity on capital markets. It is worth mentioning that first CSR indices appeared 
in the United States of America. The pioneer Domini 400 Social Index ${ }^{1}$, concentrating on socially responsible companies, was created in 1990. In 1999 Dow Jones started publishing their Dow Jones Sustainability Index. Both the success of first sustainability stock indices and growing popularity of CSR and SRI ideas resulted in their further creation among global stock exchanges (Dziawgo, 2007, pp. 123-127).

Many opponents of CSR are of the opinion that the application of any nonfinancial criteria for the selection of companies to the portfolio leads to a decrease in its effectiveness. Such claims have their origin in modern portfolio theory, because the implementation of ESG criteria often results in underweight or overweight of certain sectors in the portfolio, i.e. the problem of appropriate diversification (Jedynak, 2012, p. 167). However, the theory of management gives a different view: the implementation of CSR contributes to the increase of transparency, and this in turn contributes to a significant to reduce information asymmetry on the capital market. In addition, the company's activities in line with CSR are aimed at reducing the controversy and conflicts of individual interests stakeholder groups, which often causes crises in the enterprise and reflects on its effectiveness (Czerwińska, 2012, p. 133). One of the empirical methods enabling the verification of the statement saying that following the aspects of SRI influences the effectiveness of investments is the comparison of the profitability of SRI indices with the profitability of traditional indices The profitability assessment and measurement of socially responsible stock market indices are subject to numerous scientific publications. Research examples referring to the relationship between the results of CSR and traditional indices were presented in the table below.

Table 3. An overview of selected researches relating to the profitability of global sustainability stock market indices

\begin{tabular}{|l|l|c|c|c|}
\hline \hline $\begin{array}{c}\text { Authorship, } \\
\text { year of publication }\end{array}$ & \multicolumn{1}{|c|}{ Subject coverage } & $\begin{array}{c}\text { Geographical } \\
\text { coverage }\end{array}$ & Time coverage & Assessment \\
\hline \hline Statman, 2000 & $\begin{array}{l}\text { Domini Social Index } \\
\text { Vs. Standard \& Poor's 500 Index }\end{array}$ & USA & $1990-1998$ & positive \\
\hline $\begin{array}{l}\text { Brammer, Brooks and } \\
\text { Pavelin, 2006 }\end{array}$ & FTSE4Good vs. FTSE All-Share Index & UK & $1997-2002$ & negative \\
\hline
\end{tabular}

1 Currently known as MSCI KLD 400 Social Index. 
Table 3. An overview of selected researches...

\begin{tabular}{|c|c|c|c|c|}
\hline $\begin{array}{l}\text { Authorship, } \\
\text { year of publication }\end{array}$ & Subject coverage & $\begin{array}{l}\text { Geographical } \\
\text { coverage }\end{array}$ & Time coverage & Assessment \\
\hline $\begin{array}{l}\text { Collison, Cobb, Power } \\
\text { and Stevenson, } 2009\end{array}$ & $\begin{array}{l}\text { FTSE4Good UK and FTSE4Good } \\
\text { Europe vs. FTSE100 }\end{array}$ & UK, Europe & $1996-2005$ & neutral \\
\hline $\begin{array}{l}\text { Christofi, Christofi } \\
\text { and Sisaye, } 2012\end{array}$ & $\begin{array}{l}\text { Dow Jones Sustainability Index } \\
\text { World vs. MSCI World Index }\end{array}$ & global reach & 1999-2009 & neutral \\
\hline $\begin{array}{l}\text { Brzeszczyński } \\
\text { and McIntosh, } 2014\end{array}$ & FTSE4GOOD Index vs. FTSE100 & UK & $2000-2010$ & neutral \\
\hline Sudha, 2015 & $\begin{array}{l}\text { S\&P ESG India Index vs. Standard } \\
\text { and Poor's CNX Nifty and Standard } \\
\text { and Poor's CNX }\end{array}$ & India & $2005-2012$ & $\begin{array}{l}\text { positive/ } \\
\text { neutral }\end{array}$ \\
\hline Sikacz, 2016 & $\begin{array}{l}\text { Dow Jones Sustainability World In- } \\
\text { dex, Dow Jones Sustainability North } \\
\text { America Index, Dow Jones Sustain- } \\
\text { ability Europe Index, FTSE4GOOD } \\
\text { Global, MSCI KLD } 400 \text { Social, MSCI } \\
\text { World ESG, CALVERT Social Index } \\
\text { and STOXX Europe Sustainability } \\
\text { Index in relation to the basic days } \\
\left(28^{\text {th }} \text { September, } 2007 ; 1^{\text {st }} \text { January, }\right. \\
2010)\end{array}$ & global reach & 2010-2016 & positive \\
\hline $\begin{array}{l}\text { Brzeszczyński, Ghimire, } \\
\text { Mclntosh and Jamasb, } \\
2016\end{array}$ & $\begin{array}{l}\text { FTSE4Good Global } 100 \text { vs. Standard } \\
\text { and Poor's Global } 1200 \text {, MSCI World } \\
\text { Energy and FTSE ET50 Index }\end{array}$ & global reach & $2005-2015$ & neutral \\
\hline
\end{tabular}

S o u r c e : the author's elaboration based on: literature of the subject listed above.

It is worth explaining what exactly the evaluation notes granted stand for, i.e. assessment, and what thesis concerning the profitability of the portfolio they represent (Statman \& Glushkov, 2009, pp. 34-35):

a) positive assessment - the results of CSR indices under analysis outperformed those achieved by traditional stock market indices, as defined by "doing good while doing well",

b) neutral assessment - there is a lack of statistical differences between CSR and traditional indices, also referred to as "no effect",

c) positive/neutral assessment - the viability of CSR indices is higher during the time of crisis, however no statistical differences between their return rates and market thresholds were observed during stable periods, 
d) negative assessment - CSR and SRI pay the price in the form of worse investment results, when compared to traditional portfolios - "doing good but not well".

The results presented do not provide a clear answer on the issue of the profitability of CSR indices. In the case of the research under analysis, neutral assessment stating that there are no significant differences between the viability of CSR and non-CSR indices dominates. However, numerous market analyses indicate the profitability of following the socially responsible benchmark. Except for the viability, there are also other advantages for companies creating the indices: improvement of the reputation, promotion, access to the capital of investors who take ESG factors into account when making business decisions. It is important to ensure that the reasons for different results in table 3 may, among others, be time range, sample size, current market conditions (market crisis or stability) and the diversity of analysed sectors. Therefore, making clear conclusions with respect to the above is not possible.

\section{THE PROFITABILITY OF RESPECT INDEX - THE POLISH CSR INDEX}

Speaking of the national market it should be mentioned that Poland followed the global trend concerning sustainable development on November $19^{\text {th }}, 2009$ by creating RESPECT Index. It was the first socially responsible index in Central-Eastern Europe and the name RESPECT is an acronym representing fundamental elements of CSR and SRI, namely: Responsibility, Ecology, Sustainability, Participation, Environment, Community, Transparency. The objective of RESPECT Index is to select companies managed in a socially responsible way and stress out their investment attractiveness in terms of the level of investors relations, information and corporation governance, as well as the quality of reporting. The first RESPECT portfolio included sixteen companies listed on the Warsaw Stock Exchange (WSE). It is worth adding that the structure of the index is verified on a regular basis. Twelve editions of the project have taken place so far. The last update of companies forming the index was conducted in December 2018 - RESPECT Index now includes thirty-one companies (www1).

Therefore, the profitability of socially responsible RESPECT Index in comparison to its traditional equivalent is worth considering, as well as which thesis concerning the forming of return rate is implemented in this case. The re- 
search below presents the summary of RESPECT Index and the most knownest Polish total return index - WIG (Warsaw Stock Exchange Index ${ }^{2}$ ).

Return rates and the Sharpe ratio were selected in order to analyse the indices. Return rate, namely the measure used in all research presented in table 3 , is a classic indicator of the instrument's price fluctuations over time, providing information as to the effectiveness of the investment in comparison to others. The Sharpe ratio was used for the purpose of including the investment risk in the analysis of the profitability of investing in companies included in WIG and RESPECT. The Sharpe ratio enables selection of investments based on two criteria: profit and risk. The factor's value provides information about the risk premium for each unit of risk taken and can be calculated by the following formula (Scholz, 2007, p. 348):

$$
S_{p}=\frac{R_{p}-R_{f}}{\sigma_{p}}
$$

where:

$S_{p}$ - Sharpe ratio,

$R_{p}$ - return of portfolio,

$R_{f}$ - risk-free rate,

$\sigma_{p}$ - standard deviation of the portfolio's excess return.

Table 4. Return rates of RESPECT Index and WIG (state of the day: $27^{\text {th }}$ March, 2019)

\begin{tabular}{|l|l|l|l|l|l|l|}
\hline \hline \multirow{2}{*}{$\begin{array}{c}\text { Stock } \\
\text { market indices }\end{array}$} & \multicolumn{5}{|c|}{ Return rates in the following periods } \\
\cline { 2 - 7 } & $\mathbf{1}$ month & $\mathbf{3}$ months & $\mathbf{6}$ months & $\mathbf{1}$ year & $\mathbf{5}$ years & $\begin{array}{c}\text { From the first day of the } \\
\text { quotation of the RESPECT } \\
\text { Index (19th November, 2009) }\end{array}$ \\
\hline \hline RESPECT Index & $-2.11 \%$ & $1,91 \%$ & $2.96 \%$ & $0.79 \%$ & $12.57 \%$ & $71.37 \%$ \\
\hline WIG & $-0.2 \%$ & $3,85 \%$ & $0.93 \%$ & $0.69 \%$ & $11.98 \%$ & $51.18 \%$ \\
\hline \hline
\end{tabular}

S o u r c e : the author's elaboration based on: (www2).

2 RESPECT Index and WIG were selected for the comparison due to the same methodology of the calculation of stock indices. They are total return indices which consider both the prices of shares included, as well as income from dividends and rights issues. 
Figure 1. Yields of RESPECT Index and WIG

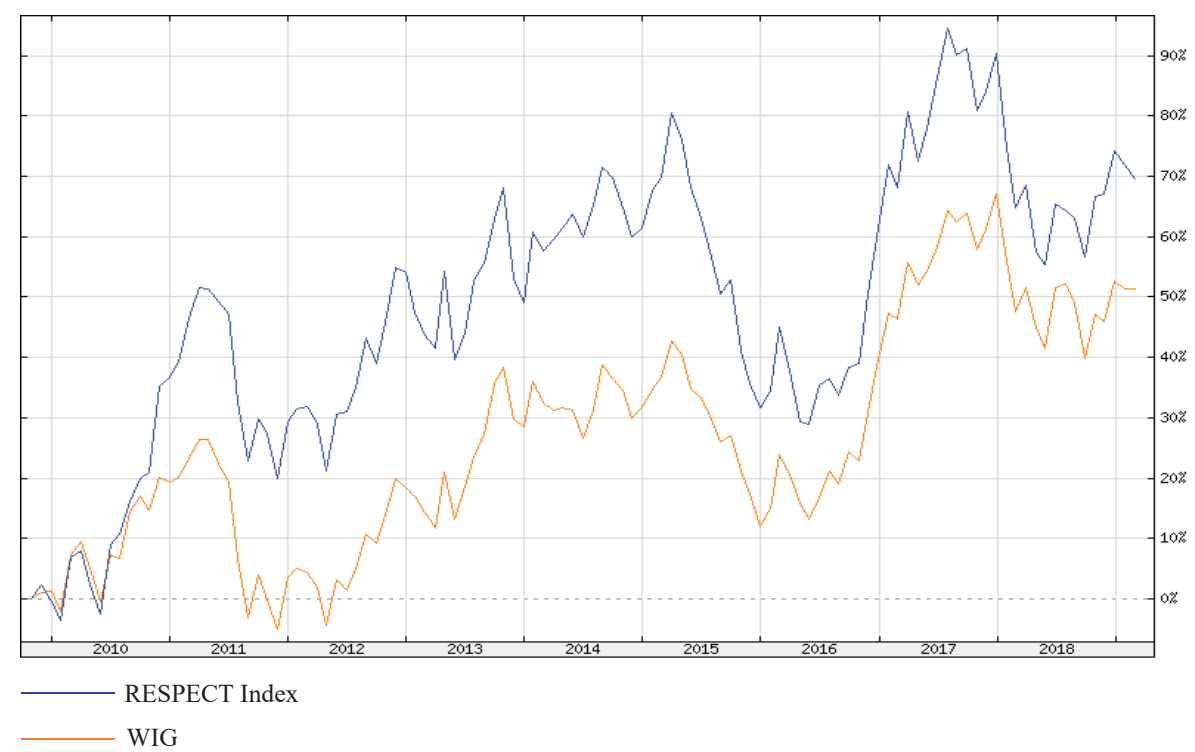

S o u r c e : the author's elaboration based on: (www2).

As can be seen in figure 1, yields of RESPECT Index is above WIG. Based on results from the table it can be concluded that in the medium- and long-term perspectives, socially responsible index performed better than WIG. However, in a short-term horizon (maximum of three months) the profitability of RESPECT Index underperformed the benchmark. Moreover, with reference to the first trading day, investing profitability in accordance with the CSR index should be assessed very positively as the return rate achieved by RESPECT was nearly 1.5 times higher than the benchmark. This argument is often presented by the WSE to prove the relevance and cost-efficiency of RESPECT project.

Table 5 contains a summary of results achieved by indices in the past two complete years. The calculations adopted the two-year interest rate of DoS0119 government bonds as the risk-free rate. The research was based on average monthly return of portfolio. Comparing the results it should be noted, that the Sharpe ratio for RESPECT Index amounts at the level higher than the research benchmark index. What should not be overlooked when seeing the negative rates, is that during the analysed period the market suffered from recession. The results should nevertheless be interpreted as a recommendation for investing in socially responsible companies, because investment strategies 
with higher Sharpe ratio are simply more effective (Haugen, 1997, pp. 380-382; Jajuga, 2006, p. 256).

Table 5. Sharpe ratio of RESPECT Index and WIG in 2017-2018

\begin{tabular}{|l|c|c|c|c|}
\hline \hline Stock market indices & $\begin{array}{c}\text { Average return } \\
\text { of portfolio }\end{array}$ & Risk-free rate & Standard deviation & Sharpe ratio \\
\hline \hline RESPECT Index & $1.6 \%$ & $2.1 \%$ & $4.65 \%$ & -0.11 \\
\hline WIG & $0.54 \%$ & $2.1 \%$ & $4.09 \%$ & -0.38 \\
\hline \hline
\end{tabular}

S o u r c e : the author's own calculations based on: (www2; Minister of Development and Finance, 2016).

To sum up, analysing only selected periods makes it impossible to verify the socially responsible investments in Poland with certainty. However, the results of research conducted present grounds to reject the "doing good but not well" thesis. Due to generally higher profitability of RESPECT Index in a medium- and long-term perspective, even though the differences are sometimes minimal, this strategy can be evaluated positively and its monitoring can be continued.

\section{CONCLUSIONS}

Implementing the concept of CSR by companies brings quantifiable and nonquantifiable benefits. Indisputably, the key nonquantifiable advantage (indirect financial factor) of considering ESG aspects in the functioning of a company is building its reputation. CSR activities are also attractive from the strictly financial perspective. Therefore, the popularity of stock indices as rating tools used to measure the effectiveness of socially responsible strategies on international capital market increases.

The results show that introducing the CSR strategy on the financial market may bring investors profits outperforming the benchmark. According to scientists who study global stock market indices, there are usually no statistical differences in the viability between classical investing and SRI. As a result, it can be concluded, that investors who follow their ethical values and invest their assets in socially responsible companies are not exposed to losses. Bearing in mind other advantages of CSR and SRI, the above fact speaks in favour of choosing socially responsible strategies. 
Moving to the national market, the comparative analysis of return rates of RESPECT Index and WIG encourages to SRI in medium- and long-term perspectives. Additionally, evaluating the profitability of indices by the Sharpe ratio it was concluded that the efficiency of RESPECT Index is higher than WIG with the same level of risk.

Finally, it has to be underlined that due to different time horizons, sample sizes and diversity of markets a holistic and unquestionable conclusion as to the cost-efficiency of socially responsible strategies cannot be drawn based on the studies. At the same time, better investment profitability (when compared to standard investments), increase in the credibility of the institution and reduction of investment risk are indubitably sufficient reasons to become interested in CSR/SRI stock market indices.

\section{REFERENCES}

Bartkowiak, G. (2011). Społeczna odpowiedzialność biznesu w aspekcie teoretycznym i empirycznym. (Corporate Social Responsibility: Theoretical and Empirical Aspects.) Warszawa: Difin.

Boatright, J.R. (2010). Finance Ethics. Critical Issues In Theory and Practice. Hoboken: John Wiley \& Sons.

Brammer, S., Brooks, C., \& Pavelin, S. (2006). Corporate Social Performance and Stock Returns: UK Evidence from Disaggregate Measures. Financial Management, 35(3), 97-116. https://dx.doi.org/10.1111/j.1755-053X.2006.tb00149.x.

Brzeszczyński, J., \& McIntosh, G. (2014). Performance of Portfolios Composed of British SRI Stocks. Journal of Business Ethics, 120(3), 335-362.

Brzeszczyński, J., Ghimire, B., Jamasb, T., \& McIntosh, G. (2016). Socially responsible investment and market performance: the case of energy and resource firms, working paper, http://www.eprg.group.cam.ac.uk/wp-content/uploads/2016/02/1605PDF.pdf (accessed: 28.03.2019).

Chandler, D., \& Werther, W.B. (2006). Strategic Corporate Social Responsibility: Stakeholders in a Global Environment. Thousand Oaks: SAGE Publications.

Christofi, A.C., Christofi, P., \& Sisaye, S. (2012). Corporate sustainability: Historical development and reporting practices. Management Research Review, 35(2), 157-173. https://dx.doi.org/10.1108/01409171211195170.

Collison, D.J., Cobb, G., Power, D.M., \& L.A. Stevenson (2008). The financial performance of the FTSE4Good indices. Corporate Social Responsibility and Environmental Management,15(1), 14-28. https://dx.doi.org/10.1002/csr.144.

Commission of the European Communities (2001). Green Paper: Promoting a European Framework for Corporate Social Responsibility, Brussels.

Czerwińska, T. (2012). Efektywność inwestycji społecznie odpowiedzialnych na rynku akcji. (The effectiveness of Social Responsible Investment on the stock market.) 
Problemy zarządzania, (Management problems.) 10/4(1), 129-140. https://dx.doi. org/10.7172/1644-9584.39.8.

Czerwonka, M. (2013). Inwestowanie społecznie odpowiedzialne. (Socially responsible investing.) Warszawa: Difin.

Czopik, S. (2017). Indeksy społecznej odpowiedzialności jako metoda pomiaru działań CSR w przedsiębiorstwach. (Indices of social responsibility as a method of measuring CSR activities in enterprises.) Ruch Prawniczy, Ekonomiczny i Socjologiczny, (Legal, Economic and Sociological Movement.) 4, 237-252. https://dx.doi.org/10.14746/ rpeis.2017.79.4.19.

Dziawgo, D. (2007). Ekologiczne indeksy giełdowe. (Environmental Stock Market Indices.) Ekonomia i Środowisko, (Economics and Environment.) 1(31), 121-133.

Dziawgo, D. (2011). Relacje Inwestorskie. Ewolucja - funkcjonowanie - wyzwania. (Investor Relations. Evolution - functioning - challenges.) Warszawa: PWN.

Dziawgo, L. (2010). Zielony rynek finansowy. Ekologiczna ewolucja rynku finansowego. (Green financial market. Financial market ecological evolution.) Warszawa: PWE.

European Commission (2011). The European Commission's strategy on CSR 2011-2014: achievements, shortcomings and future challenges, Brussels.

Grzybowski, M. (2004). Firma odpowiedzialna społecznie. Filozofia przedsiębiorstwa XXI wieku. (A socially responsible company. Philosophy of the 21st century enterprise.) In T. Kamiński, W. Pomykało (Eds.). Społeczna rola współczesnego marketingu. Materiały konferencyjne. (The social role of modern marketing. Conference materials.) Warszawa: Fundacja Innowacja.

Haugen, R.A. (1997). Teoria nowoczesnego inwestowania. (The theory of modern investment.) Warszawa: WIG-Press.

Jajuga, K. (2006). Inwestycje. (Investments.) Warszawa: PWN.

Jamka, B. (2011). Czynnik ludzki we współczesnym przedsiębiorstwie: zasób czy kapitał? (Human factor in a modern enterprise: resource or capital?) Warszawa: Wolters Kluwer.

Jedynak, T. (2012). Efektywność strategii inwestycji w akcje spółek społecznie odpowiedzialnych na przykładzie Respect Index. (The effectiveness of the strategy of investment in socially responsible stocks - the case of Respect Index.) Zeszyty Naukowe Polskiego Towarzystwa Ekonomicznego, (Scientific Journal of the Polish Economic Society.) 12, 161-172.

Lawrence, A.T., \& Weber, J. (2008). Business and Society. Stakeholders, Ethics, Public Policy: 12th Edition. New York: McGraw-Hill Irwin.

Lulewicz-Sas, A. (2013). Wpływ podejmowanych przez przedsiębiorstwa inicjatyw społecznie odpowiedzialnych na wartość organizacji. (The impact of the socially responsible initiatives taken by the company on the value of the organization.) Ekonomia i Zarządzanie, (Economics and Management.) 5(2), 242-254.

Łudzińska, K. (2009). Społeczna odpowiedzialność przedsiębiorstw i jej wpływ na budowę wartości. (Corporate social responsibility and its impact on building value.) In A.T. Szablewski (Ed.). Migracja kapitału w globalnej gospodarce. (Capital migration in the global economy.) Warszawa: Difin.

Łukasiewicz-Kamińska, A. (2011). Społeczna odpowiedzialność przedsiębiorstwa finansowego. (Corporate Social Responsibility of a financial company.) Warszawa: Difin. 
Minister of Development and Finance (2016). Letter of Issue No. 68/2016 of the Ministry of Development and Finance of December 21, 2016 regarding the issue of two-year savings treasury bonds with fixed interest rates offered in the retail sales network, http://www.obligacjeskarbowe.pl/media_files/90d36c65-a59d-4244-8fac63598e846944.pdf (accessed: 29.03.2019).

Paliwoda-Matiolańska, A. (2009). Odpowiedzialność społeczna $w$ procesie zarządzania przedsiębiorstwem. (Social responsibility in the business management proces.) Warszawa: C.H. Beck.

Rok, B. (2001). System społecznej odpowiedzialności. (System of social responsibility.) In: B. Rok (Ed.). Więcej niż zysk czyli odpowiedzialny biznes. Programy, strategie, standardy. (More than profit or responsible business. Programs, strategies, standards.) Warszawa: Forum Odpowiedzialnego Biznesu.

Roszkowska, P. (2011). Rewolucja w raportowaniu biznesowym. Interesariusze, konkurencyjność, społeczna odpowiedzialność. (Revolution in business reporting. Stakeholders, competitiveness, social responsibility.) Warszawa: Difin.

Scholz, H. (2007). Refinements to the Sharpe ratio: Comparing alternatives for bear markets. Journal of Asset Management, 7(5), 347-357. https://dx.doi.org/10.1057/ palgrave.jam.2250040.

Sikacz, H. (2016). Porównanie wyników wybranych indeksów giełdowych przedsiębiorstw społecznie odpowiedzialnych na świecie. (Comparison of the Results of Some Stock Market Indices for Listed Corporations Socially Responsible in the World.) Acta Universitatis Lodziensis: Folia Oeconomica, 324(4), 213-225.

Statman, M. (2000). Socially Responsible Mutual Funds. Financial Analysts Journal, 56(3), 30-39.

Statman, M., \& Glushkov, D. (2009). The Wages of Social Responsibility. Financial Analysts Journal, 65(4), 33-46. https://dx.doi.org/10.2469/faj.v65.n4.5.

Sudha, S. (2015). Risk-return and Volatility analysis of Sustainability Index in India. Environment, Development and Sustainability: A Multidisciplinary Approach to the Theory and Practice of Sustainable Development, 17(6), 1329-1342. https://dx.doi. org/10.1007/s10668-014-9608-8.

Wawrzyniak, B. (1999). Odnawianie przedsiębiorstwa. Na spotkanie XXI wieku. (Renewing an enterprise. For the 21st century meeting.) Warszawa: Poltext.

Wolska, M., \& Czerwonka, M. (2013). Społecznie odpowiedzialne inwestowanie - analiza rentowności funduszy SRI w Polsce. (Socially Responsible Investing. Profitability Analysis of SRI Funds in Poland.) Studia i Prace Kolegium Zarzq̨dzania i Finansów, (Studies and Works of the Collegium of Management and Finance.) 126, 9-21.

Wronka, M. (2011). Metody pomiaru CSR. (CSR measurement methods.) In M. Bonikowska, M. Grewiński (Eds.). Usługi społeczne odpowiedzialnego biznesu. (Social services of responsible business.) Warszawa: Wydawnictwo Wyższej szkoły Pedagogicznej w Warszawie.

Zbiegień-Maciąg, L. (1996). Etyka w Zarzq̨dzaniu. (Ethics in Management.) Warszawa: Centrum Informacji Menedżera.

(www1) RESPECT Index, http://www.odpowiedzialni.gpw.pl (accessed: 26.03.2019).

(www2) Stooq, http://stooq.pl/q/?s=respect\&d=20190326\&c=mx\&t=l\&a=ln\&r=wig (accessed: 28.03.2019). 